\title{
Model Simulasi Antrian Dengan Metode Kolmogorov-Smirnov Normal Pada Unit Pelayanan
}

\author{
Ade Pratama \\ Program Studi Pendidikan Informatika ,STKIP PGRI Sumatera Barat \\ pade85@ymail.com
}

http://dx.doi.org/10.22202/jei.2014.v1i1.1446

\begin{abstract}
ABSTRAK
Penelitian ini dilakukan untuk merancang model antrian pada unit pelayanan mahasiswa UPI-YPTK Padang.Data dikumpulkan melalui observasi ke lapangan yang selanjutnya data di analisa dengan teknik statistika untuk menentukan model antrian yang tepat. Metode yang digunakan untuk pengujian distribusi data waktu antar kedatangan dan pelayanan adalah dengan Kolmogorov-Smirnov Normal. setelah data dinyatakan sesuai dengan pengujian hipotesa kemudian digambarkan dalam bentuk media animasi antrian. Adapun Jumlah mahasiswa yang dijadikan simulasi sebanyak 120 sampel data dengan Ratarata waktu antar kedatangan mahasiswa adalah 277.78 detik, Rata-rata waktu Pelayanan adalah 221.98 detik, Rata-rata banyaknya pengantri dalam sistem adalah : 225 Orang, Rata-rata waktu antri adalah : 14.06 Menit
\end{abstract}

Kata Kunci : Simulasi, Penggunaan Statistik Dalam Simulasi, Persiapan Analisis Data, Distribusi Normal, Uji Kolmogorov-Smirnov, Frekuensi kumulatif

\section{PENDAHULUAN}

Kebutuhan layanan sangatlah penting bagi semua kalangan. Termasuk kalangan, mahasiswa yang ingin mendapatkan pelayanan pada bagian unit pelayanan mahasiswa. Masalah antrian merupakan fenomena yang sering dihadapi oleh unit pelayanan mahasiswa. Jika jumlah antrian terlalu sedikit sementara orang yang melayani terlalu banyak, maka hal ini akan mengakibatkan biaya yang dikeluarkan menjadi tidak seimbang, di lain pihak jika antrian terlalu banyak dan orang yang melayani sedikit, maka waktu tunggu menjadi semakin lama dan tingkat kepuasan mahasiswa menjadi rendah, serta perlu disediakan ruang yang lebih besar. Hal ini bisa disebabkan oleh kualitas orang yang melayani terlalu rendah karena kurang kemampuan dan pengetahuannya, baik kemampuan menanggapi masalah akademis, maupun kemampuan dibidang komputer sebagai alat pendukung kerja yang utama.

Untuk melihat dan mendapatkan jumlah antrian yang tepat, serta bisa melihat kebutuhan mahasiswa, Manajemen kampus harus sering mendapatkan kajian terhadap masalah tersebut. Mereka memerlukan survei dibagian pelayanan mahasiswa, menganalisis data dan jumlah layanan, mengamati pola antrian, mengamati keterkaitan dan kegiatan lain-lainnya. Salah satu kajian yang bisa dilakukan untuk mengetahui kondisi layanan mahasiswa adalah dengan mengamati jumlah mahasiswa yang membutuhkan layanan, jenis layanan dan dilanjutkan dengan 
melakukan analisis data, Adapun alat analisis yang digunakan adalah dengan melakukan uji asumsi normalitas data, Uji normalitas bertujuan untuk mengetahui apakah suatu variabel mempunyai distribusi data yang normal atau tidak. Untuk menguji normalitas data suatu penelitian, salah satu alat yang digunakan adalah menggunakan uji Kolmogorov -Smirnov. Menurut Ghozali (2005).

Beberapa aktivitas yang dilakukan pada unit pelayanan mahasiswa adalah pembuatan surat keterangan kuliah, pembuatan surat pengantar skripsi, pembuatan surat pengantar bimbingan, legalisir ijazah, revisi jadwal dosen, penyerahan kartu hasil studi (KHS), revisi kartu registrasi studi (KRS). Terdapat sejumlah mahasiswa maupun alumni yang melakukan aktivitas di unit pelayanan tersebut pada setiap hari kerja. Pada umumnya setiap mahasiswa mengharapkan untuk segera mendapatkan pelayanan dari unit pelayanan tanpa harus menunggu lama.dengan begitu banyaknya mahasiswa harus antri untuk bisa mendapatkan layanan dari unit pelayanan mahasiswa. Jadi jumlah unit pelayanan mahasiswa disediakan setiap saat mulai dari jam 08.00 pagi hingga jam 12.00 siang untuk digunakan oleh mahasiswa dan setelah itu jam 13.30 hingga jam 15.30.

$$
\text { Pada jam-jam tertentu unit }
$$
pelayanan mahasiswa melayani mahasiswa dalam keadaan menganggur (Idle), karena tidak ada mahasiswa yang dilayani. Tapi lain waktu, banyak mahasiswa yang antri karena hampir semua unit pelayanan yang ada digunakan oleh mahasiswa (dalam keadaan sibuk). Timbulnya tuntutan efisiensi waktu dalam menyelesaikan pekerjaan sangat berkaitan erat dengan sistem antrian dimana didalamnya tercakup jumlah layanan yang dimiliki unit pelayanan mahasiwa. Sebab mahasiswa terpaksa menunggu dalam antrian panjang namun bila terlalu banyak / unit pelayanan kondisi menganggur (tidak sibuk) akan menambah biaya. Begitu juga, jika terlalu banyak mahasiswa yang antri, akan mengurangi layanan yang prima.

Masalah antrian merupakan permasalahan operasional yang sering dihadapi, berapa kemungkinan mahasiswa yang datang dan berapa aktivitas diselesaikan dalam waktu singkat. Sistem antrian ini perlu dibuat untuk melihat ratarata banyaknnya pengantri dalam sistem, rata-rata banyaknya pengantri yang sedang antri, rata-rata waktu menunggu dalam sistem, rata-rata waktu antri, proporsi waktu berhenti melayani.

Berdasarkan uraian, maka penulis tertarik untuk merancang suatu sistem yang bekerja secara komputerisasi dan mencoba untuk merancang bentuk model antrian berupa media animasi, dengan didukung macromedia flash 8 diharapkan keberadaan media ini dapat memudahkan dalam proses penyampaian informasi dan dapat dikembangkan untuk penelitian selanjutnya.

\section{PengujianKolmogorov-Smirnov Normal}

Pengujian bertujuan melihat tingkat kesesuaian antara fungsi distribusi hasil pengamatan dengan fungsi distribusi teoritik tertentu, dengan menetapkan suatu titik yang menggambarkan perbedaan maksimum keduanya.

1. Menentukan Statistik Uji

Thitung $=\operatorname{Maks}|F(x)-S(x)|$

Di mana:

$\mathrm{F}(\mathrm{x})=$ fungsi distribusi kumulatif dari suatu distribusi normal 
$S(x)=$ fungsi distribusi kumulatif dari suatu distribusi pengamatan

2. Menentukan Kriteria Penolakan

Jika nilai Thitung $\geq \mathrm{W}_{1-\alpha}$, maka $\mathrm{H}_{0}$ ditolak (tabel yang digunakan adalah tabel (Kolmogorov-Smirnov). Langkah-langkah Pengujian :

a. Menetapkan hipotesis awal dan hipotesis tandingan

Hipotesis: $\mathrm{H}_{0}$ : data mengikuti distribusi normal $\mathrm{H}_{1}$ : data tidak mengikuti distribusi normal

b. Menghitung Statistik Uji

Banyaknya parameter pada distribusi normal adalah yang menyatakan nilai rata-rata. Untuk menentukan harga $F(x)$ maka nilai harus ditentukan dengan cara :

$$
\bar{X}=\frac{\sum_{i=1}^{n} X_{i .} f i}{n}
$$

Di mana :

$n=$ jumlah sampel yang diambil

$X i=$ nilai tengah

$f i=$ frekuensi

$$
Z=\frac{x-\mu}{\sigma}
$$

Di mana :

$Z=$ distribusi normal standar

$x=$ nilai tengah

$\mu=$ rata- rata

$\sigma=$ standard deviasi dari distribusi

Untuk mencari $F(x)$ dengan

menggunakan tabel distribusi normal sesuai nilai $Z$ yang didapatkan. $S(x)$ diperoleh dari frekuensi kumulatif masing-masing nilai $x i$ dibagi dengan jumlah sampel.

3. Menetapkan $\alpha$ (taraf signifikansi). $\alpha=0,05$

4. Menentukan daerah penolakan.

$\mathrm{W}_{1-\alpha}$ didapatkan dari tabel Kolmogorov-

Smirnov sesuai dengan $n$ yang ada dan

simpangan baku yang didapatkan.

tabelKolmogorov-Smirnov

5. Membuat kesimpulan.

Membandingkan antara Thitung dengan $\mathrm{W}_{1-\alpha}$, jika Thitung $<\mathrm{W}_{1-\alpha}$ maka $\mathrm{H}_{0}$ gagal tolak dan bila nilai Thitung $\geq \mathrm{W}_{1-\alpha}$, maka $\mathrm{H}_{0}$ ditolak.

6. Membuat interpretasi dari kesimpulan.

Jika $\mathrm{H}_{0}$ gagal tolak/ diterima maka data yang diuji adalah berdistribusi normal.

\section{Diagram Penentuan Model Antrian Dan Pembahasan}

Ketidakpastian Kedatangan pada unit pelayanan menimbulkan adanya banyak kemungkinan-kemungkinan, pada saat kondisi perkuliahan normal terlihat tidak terlalu banyak mahasiswa yang mengantri, namun lonjakan akan terjadi bila suatu kalender akademik memungkinkan mahasiswa semakin banyak yang datang untuk mendapatkan layanan dibagian unit pelayanan. Salah satu cara untuk memperkecil kemungkinan tersebut adalah dengan mempelajari distribusi probabilitas tingkat kedatangan dan pelayanan mahasiswa. Distribusi probabilitas secara teoritis yang sering digunakan adalah distribusi normal.

Untuk menentukan model antrian pada unit pelayanan mahasiswa UPI "YPTK" Padang terlebih dahulu digambarkan langkah-langkah bagaimana untuk penentuan pola distribusinya.selanjutnya dari langkah berdasarkan diagram ditentukanlah perhitungan sekaligus pembahasan yang menggunakan perhitungan teknik statistik seperti yang 
telah dijelaskan. Setelah perhitungan yang sudah didapatkan maka hipotesa akan diuji dengan Kolmogorov-Smirnov Normal. Langkah-langkah penentuan pola distribusinya dapat dilihat pada Gambar 1

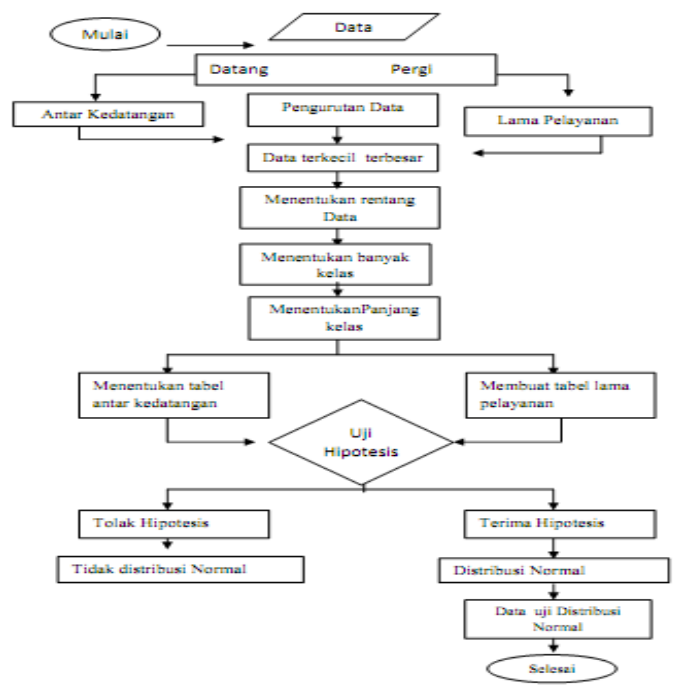

Gambar 1

\section{Pengolahan Data}

Pada tahap ini dilakukan pengolahan terhadap data yang diperoleh dari pengamatan, yaitu data waktu antar kedatangan mahasiswa dan waktu pelayanan mahasiswa.

\section{Perancangan Untuk Program Simulasi}

Program simulasi antrian pada unit pelayanan mahasiswa dirancang dengan menggunakan bahasa pemrograman microsoft visual basic 6.0 dengan didukung oleh beberapa komponen tambahan seperti shockwave flash. Dalam membuat simulasi ini penulis juga menggunakan macromedia flash 8 untuk membuat animasi yang diperlukan untuk mendukung performa tampilan yang lebih baik.

\section{Perancangan Tampilan}

Tampilan menu, dirancang dalam dua bentuk.yang pertama dalam bentuk hirarki dan yang kedua dalam bentuk desain seperti yang terlihat pada Gambar 2

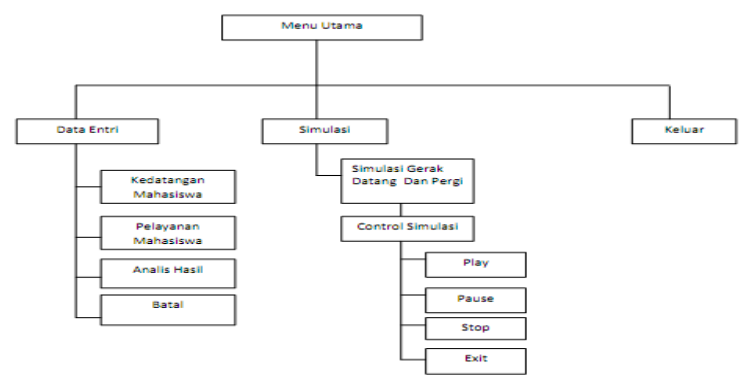

Gambar 2

\section{HASIL DAN IMPLEMENTASI}

Dari pembahasan yang telah dilakukan berdasarkan data yang dikumpulkan dengan menggunakan teknik statistik, maka kemudian dilakukanlah implementasi dengan menggunakan perangkat lunak Microsoft Visual Basic 6.0 adapun langkahlangkah yang dilakukan adalah sebagai berikut :

\section{Menyelesaikan Disain Sistem}

Mempersiapkan program untuk pengolahan data yang diinput dan output dari waktu antar kedatangan dan waktu layanan pada unit Pelayanan mahasiswa " UPI-YPTK “ Padang, maka dibentuklah disain Form Pemasukan / List Antar Kedatangan seperti yang terlihat pada Gambar 3

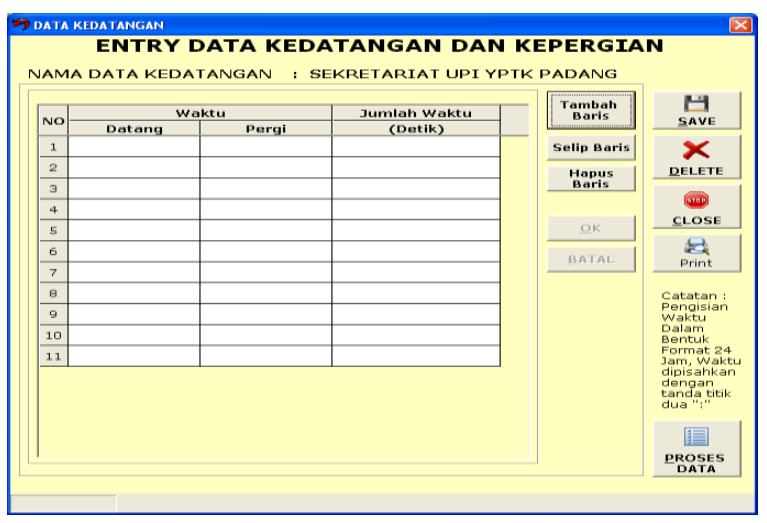

Gambar 3 
Penelitian Bidang Komputer Sains dan Pendidikan Informatika V1.i1(91-102)

Form Pemasukan / List Mulai -Akhir untuk waktu Layanan seperti yang terlihat pada Gambar 4

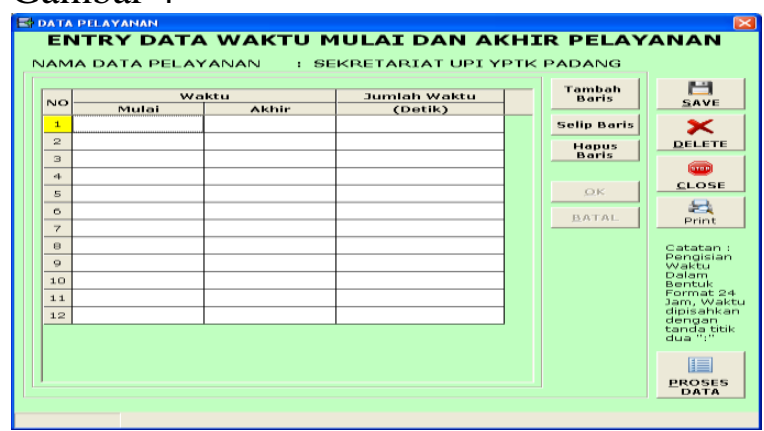

Gambar 4

Selanjutnya dibentuklah Form Pendugaan Distribusi Frekuensi Waktu Antar Kedatangan Mahasiswa seperti yang terlihat pada Gambar 5

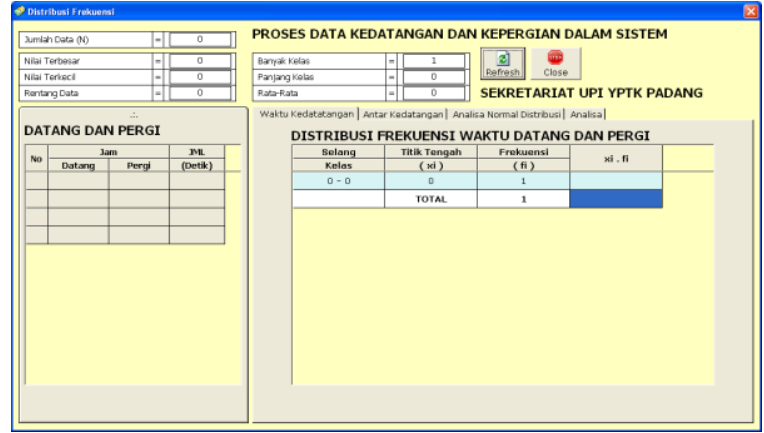

Gambar 5

Dan Form Pendugaan Distribusi Frekuensi Waktu Pelayanan Mahasiswa seperti yang terlihat pada Gambar 6

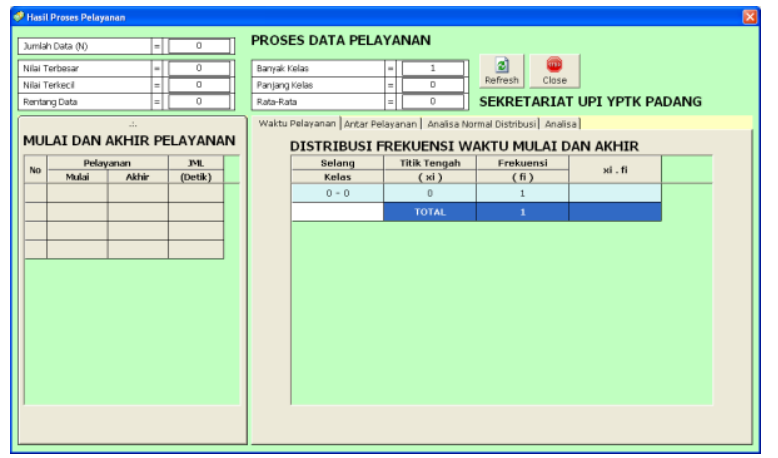

Gambar 6

Menulis Program Dan Hasil Program
Persiapan untuk merancang program menggunakan Microsoft Visual Basic 6.0 sehingga instruksi atau perintah yang diberikan dapat dimengerti oleh Komputer.dari hasil program yang telah dimasukkan data adalah waktu antar kedatangan mahasiswa dan waktu pelayanan mahasiswa seperti pada Gambar 7

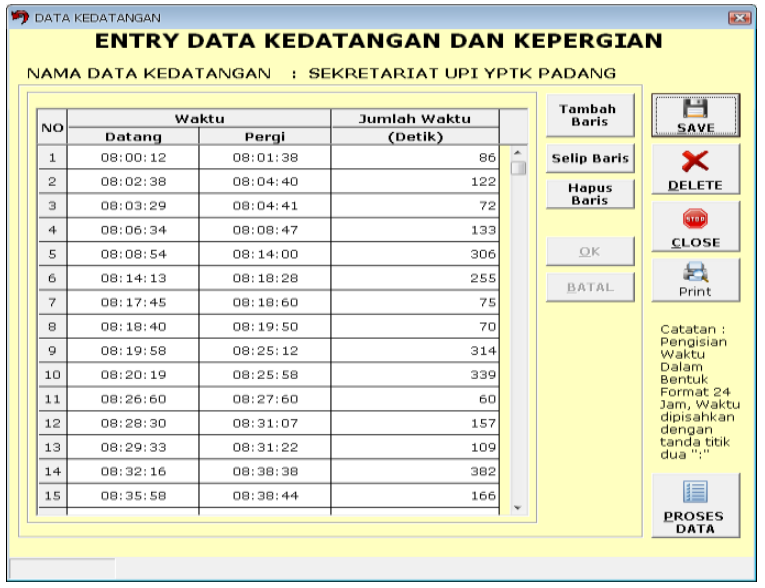

\section{Gambar 7}

Data waktu antar kedatangan mahasiswa adalah waktu yang menunjukan saat tibanya mahasiswa diujung antrian atau ke depan unit pelayanan sampai pergi meninggalkan unit pelayanan / selesai dilayani, dihitung dalam satuan detik.Setelah data dimasukkan kemudian dilakukan proses ke tahap selanjutnya yaitu menghasilkan Pendugaan Distribusi Frekuensi waktu datang dan pergi seperti pada Gambar 8

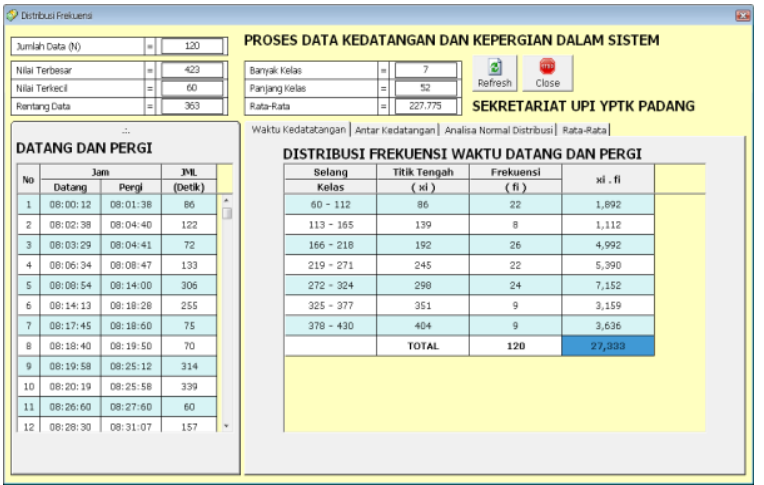




\section{Gambar 8}

Data Waktu Antar Kedatangan Mahasiswa dikelompokkan ke dalam beberapa kelas dan kemudian dihitung jumlah data yang masuk ke dalam setiap kelas, atau disebut distribusi frekuensi.Setelah itu dilanjutkan dengan proses Pendugaan Distribusi Waktu Antar Kedatangan seperti yang terlihat pada Gambar 9

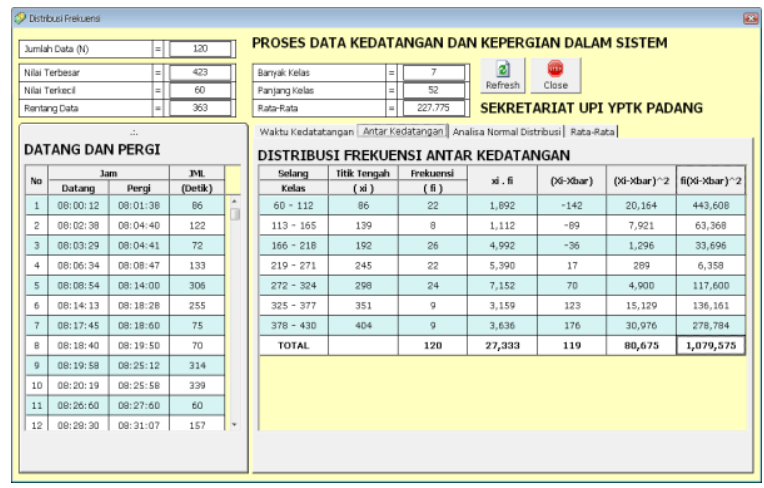

\section{Gambar 9}

Untuk mengetahui distribusi data seperti yang terlihat pada gambar diatas maka dilakukan uji distribusi. Adapun proses Pengujian Distribusi data yaitu :

1.

Nilai $\quad X i \quad$ (nilai tengah) diperoleh dari perhitungan masing-masing selang kelas

2. Nilai (frekuensi) adalah kemungkinan munculnya nilai (angka) yang diperoleh berdasarkan data sample.

3. Nilai xi.fi diperoleh dari hasil perkalian masingmasing nilai $\mathrm{Xi}$ dan nilai $f i$.

4. Nilai (Xi - Xbar) / rata-rata diperoleh dari dari hasil pengurangan masing-masing nilai titik tengah dengan nilai Xbar / rata-rata.

5. Nilai (Xi -Xbar) $\wedge^{2}$ diperoleh dari masing-masing nilai $\mathrm{Xi}$ - Xbar dipangkatkan.
6.

Nilai fi $(\mathrm{Xi}-$ Xbar) $\wedge^{2}$ diperoleh dari perkalian masing-masing nilai $f i$ dengan nilai $(X \mathrm{X}$ - Xbar) $\wedge^{\wedge}$.

Setelah dilakukan proses Distribusi waktu antar kedatangan kemudian dilanjutkan dengan proses Analisa Normal distribusi Antar Kedatangan seperti yang terlihat pada Gambar 10

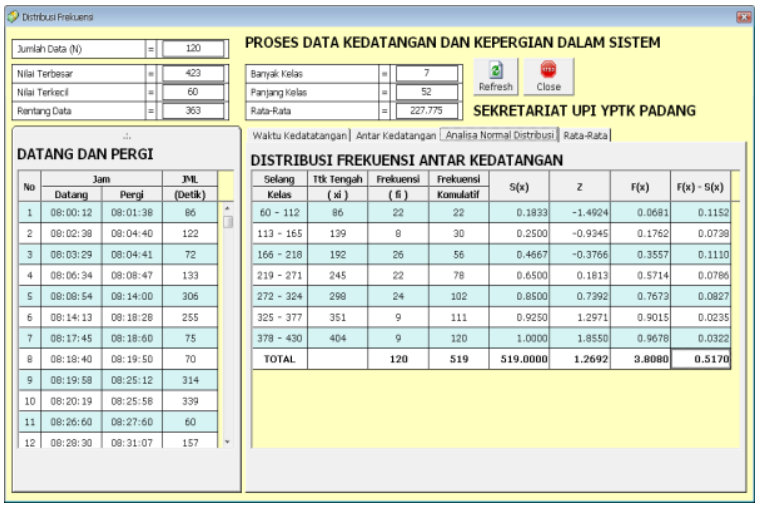

Gambar 10

Untuk mengetahui proses analisa normal distribusi antar kedatangan seperti yang terlihat pada gambar diatas maka dilakukan langkah-langkah sebagai berikut :

1 .

Mencari nilai

Frekuensi kumulatif dari masingmasing kelas. Selanjutnya mencari nilai $\mathrm{S}$ (simpangan baku atau standar deviasi) dari data sample (n). Didapatkan nilai simpangan baku sebesar 94.84

2. Nilai $\quad \mathrm{S}(\mathrm{X})$ diperoleh dari masing-masing nilai frekuensi kumulatif dibagi dengan Total sample data.

Nilai Z diperoleh dari nilai masing-masing nilai titik tengah dikurangi dengan nilai rata-rata dan dibagi dengan nilai simpangan baku. Setelah ditemukan nilai $\mathrm{Z}$ masing-masingnya kemudian dicocokkan dengan table normal untuk memperolehnorm distr $\mathrm{F}(\mathrm{X})$ 
4.

Nilai $\mathrm{F}(\mathrm{X})-\mathrm{S}(\mathrm{X})$ diperoleh dari hasil pengurangan masing-masing nilai $\mathrm{F}(\mathrm{X})$ dan nilai $\mathrm{S}(\mathrm{X})$.

5 .

selanjutnya adalah melihat nilai yang tertinggi dari hasil pengurangan $\mathrm{F}(\mathrm{X})$ $\mathrm{S}(\mathrm{X}) /$ Thitung .dari proses Thitung didapat nilai sebesar 0.1152 .

6.

Kemudian

dilanjutkan dengan proses pengujian hipotesa yang diasumsikan sesuai dengan rumus, dan didapatkan nilai $\mathrm{W}_{1-\mathrm{a}}$ sebesar 0.1241

7. selanjutnya adalah membandingkan nilai yang diperoleh dari nilai Thitung dengan asumsi pengujian hipotesa. Seperti yang sudah dibahas pada bab sebelumnya.

8.

Pengujian Distribusi data Waktu Antar Kedatangan Mahasiswa didapat nilai Thitung lebih kecil dibandingkan dengan nilai $\mathrm{W}_{1-\mathrm{a}}$ (asums pengujian hipotesa) sehingga dapat ditarik kesimpulan bahwa pengujian Data Waktu Antar Kedatangan Mahasiswa Berdistribusi Normal

Setelah itu diperoleh rata-rata waktu antar kedatangan seperti yang terlihat pada Gambar 11

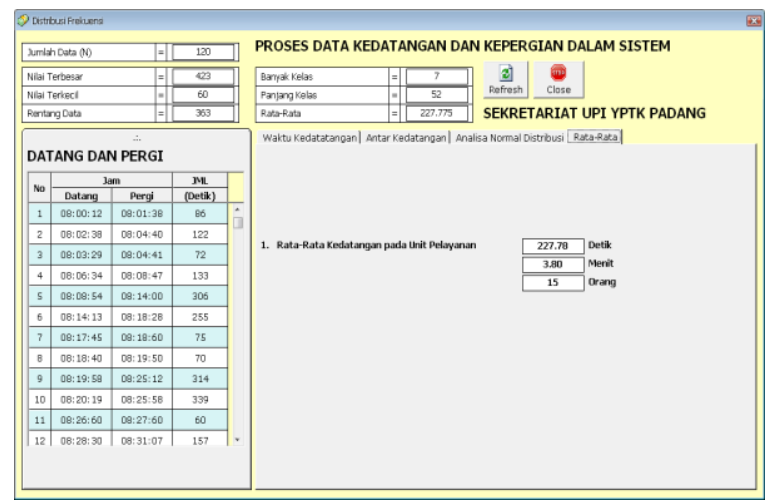

\section{Gambar 11}

Rata-rata Waktu Antar Kedatangan Mahasiswa diperoleh dari perhitungan Total Nilai Fi * Xi dibagi dengan Total Sample data, dan didapat nilai sebesar 227.78 detik kemudian nilai tersebut dibagi 60 untuk mendapatkan satuan 3.80 per menit dan dibagi 60 untuk satuan 15 Orang per jam.

Setelah proses waktu antar kedatangan selesai kemudian dilanjutkan pada proses berikutnya yaitu data dimasukkan kedalam Form Pelayanan seperti yang terlihat pada Gambar 12

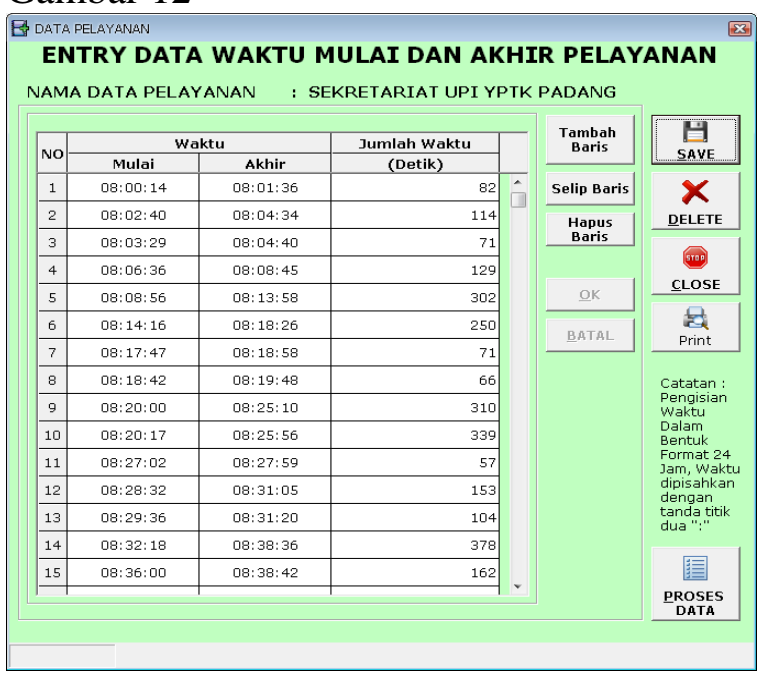

\section{Gambar 12}

Data Waktu Pelayanan mahasiswa adalah waktu yang menunjukan saat unit pelayanan mahasiswa mulai melayani sampai selesai melayani mahasiwa. Setelah dimasukkan data maka diproses akan menghasilkan proses pendugaan Distribusi Frekuensi waktu mulai dan akhir pelayanan seperti pada Gambar 13 


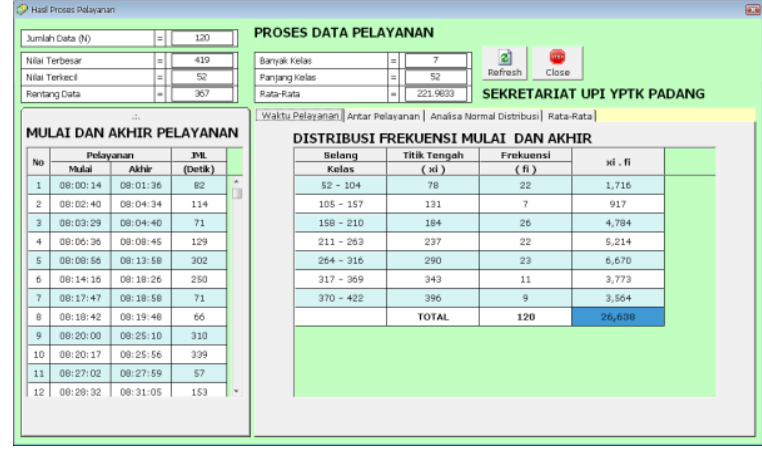

\section{Gambar 13}

Data Waktu Pelayanan Mahasiswa dikelompokkan ke dalam beberapa kelas dan kemudian dihitung jumlah data yang masuk ke dalam setiap kelas, atau disebut distribusi frekuensi. Setelah itu dilanjutkan dengan proses Distribusi Waktu pelayanan seperti yang terlihat pada Gambar 14

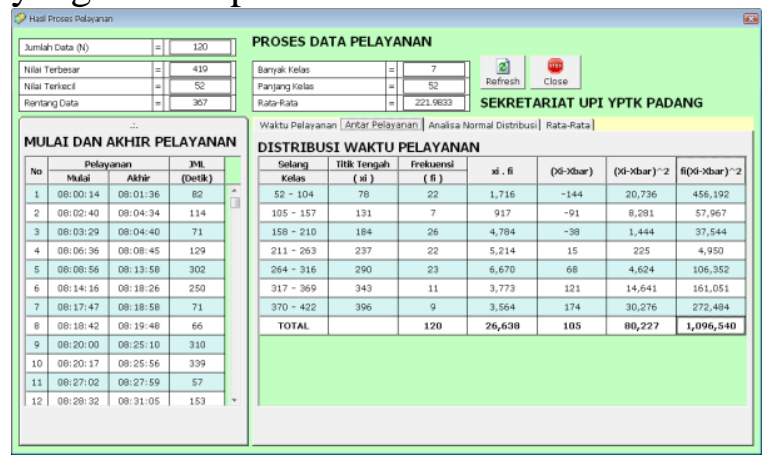

Gambar 14

Untuk mengetahui distribusi data seperti yang terlihat pada gambar diatas maka dilakukan uji distribusi. Adapun proses Pengujian Distribusi data yaitu :

1. Nilai $X i$ (nilai tengah) diperoleh dari perhitungan masing-masing selang kelas

2.

Nilai

(frekuensi) adalah kemungkinan munculnya nilai (angka) yang diperoleh berdasarkan data sample.

3. Nilai $\quad$ xi. $f i$ diperoleh dari hasil perkalian masingmasing nilai Xi dan nilai $f i$.

4.

Nilai (Xi - Xbar)

I rata-rata diperoleh dari dari hasil pengurangan masing-masing nilai titik tengah dengan nilai Xbar / rata-rata.

5.

Nilai $(\mathrm{Xi}-\mathrm{Xbar})$ $\wedge^{2}$ diperoleh dari masing-masing nilai $\mathrm{Xi}$ - Xbar dipangkatkan.

6.

Nilai fi (Xi Xbar) $\wedge^{2}$ diperoleh dari perkalian masing-masing nilai $f$ dengan nilai $(\mathrm{Xi}$ $-\mathrm{Xbar})^{\wedge}{ }^{2}$.

Setelah dilakukan proses Distribusi waktu pelayanan kemudian dilanjutkan dengan proses Analisa Normal distribusi Layanan seperti yang terlihat pada Gambar 15

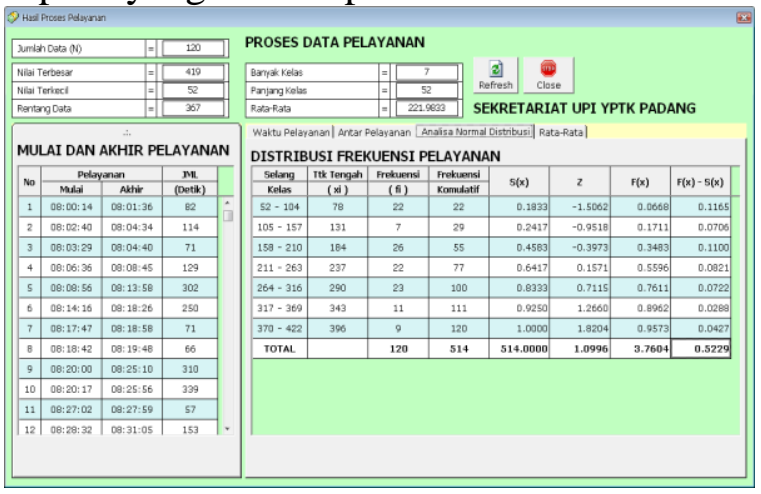

Gambar 15

Untuk mengetahui proses analisa normal distribusi Pelayanan Mahasiswa seperti yang terlihat pada gambar diatas maka dilakukan langkah-langkah sebagai berikut :

1.

Frekuensi kumulatif dari masingmasing kelas.

2.

mencari nilai $\mathrm{S}$ (simpangan baku atau standar deviasi) dari data sample (n). Didapatkan nilai simpangan baku sebesar 95.59

3.

diperoleh dari masing-masing nilai frekuensi kumulatif dibagi dengan Total sampel data.

4.

Nilai Z diperoleh dari nilai masing-masing nilai titik tengah dikurang dengan nilai rata-rata 
dan dibagi dengan nilai simpangan baku. Setelah ditemukan nilai $\mathrm{Z}$ masing-masingnya kemudian dicocokkan dengan table normal untuk memperolehnorm distr $\mathrm{F}(\mathrm{X})$

5 .

Nilai $F(X)-S(X)$ diperoleh dari hasil pengurangan masing-masing nilai $F(X)$ dan nilai $\mathrm{S}(\mathrm{X})$.

6.

selanjutnya adalah melihat nilai yang tertinggi dari hasil pengurangan $\mathrm{F}(\mathrm{X})$ $\mathrm{S}(\mathrm{X}) /$ Thitung . dari proses Thitung didapat nilai sebesar 0.1165

7.

Kemudian

dilanjutkan dengan proses pengujian hipotesa yang diasumsikan sesuai dengan rumus, dan didapatkan nilai $\mathrm{W}_{1 \text {-a }}$ sebesar 0.1241

8.

Langkah

selanjutnya adalah membandingkan nilai yang diperoleh dari nilai Thitung dengan asumsi pengujian hipotesa. Seperti yang sudah dibahas pada bab sebelumnya.

9.

Pengujian Distribusi data Waktu Pelayanan Mahasiswa didapat nilai Thitung lebih kecil dibandingkan dengan nilai $\mathrm{W}_{1-\mathrm{a}}$ (asumsi pengujian hipotesa) sehingga dapat ditarik kesimpulan bahwa pengujian Data Waktu Pelayanan Mahasiswa Berdistribusi Normal.

Setelah itu diperoleh rata-rata waktu Pelayanan seperti yang terlihat pada Gambar 16

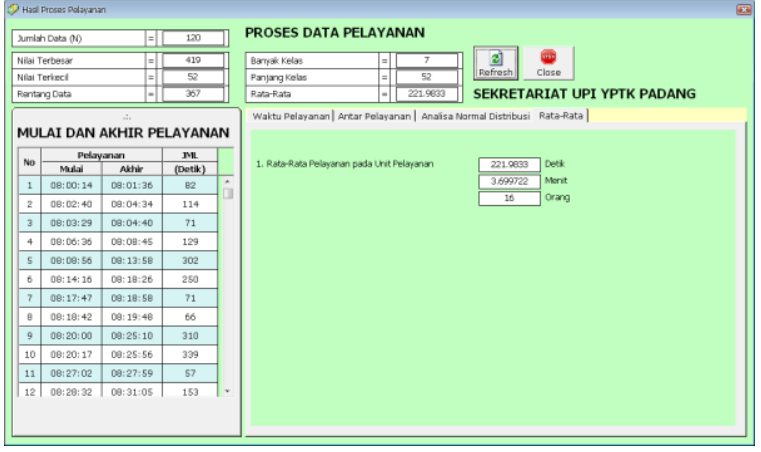

Gambar 16

Rata-rata Waktu Pelayanan Mahasiswa diperoleh dari perhitungan Total Nilai Fi * $\mathrm{Xi}$ dibagi dengan Total Sample data, dan didapat nilai sebesar 221.98 detik kemudian nilai tersebut dibagi 60 untuk mendapatkan satuan 3.70 per menit dan dibagi 60 untuk satuan 16 Orang per jam.

\section{Analisa Hasil Pengujian}

Dari hasil perhitungan pembahasan yang didapat dari waktu antar kedatangan dan waktu pelayanan maka dapat diperoleh hasil seperti yang terlihat pada Gambar 17

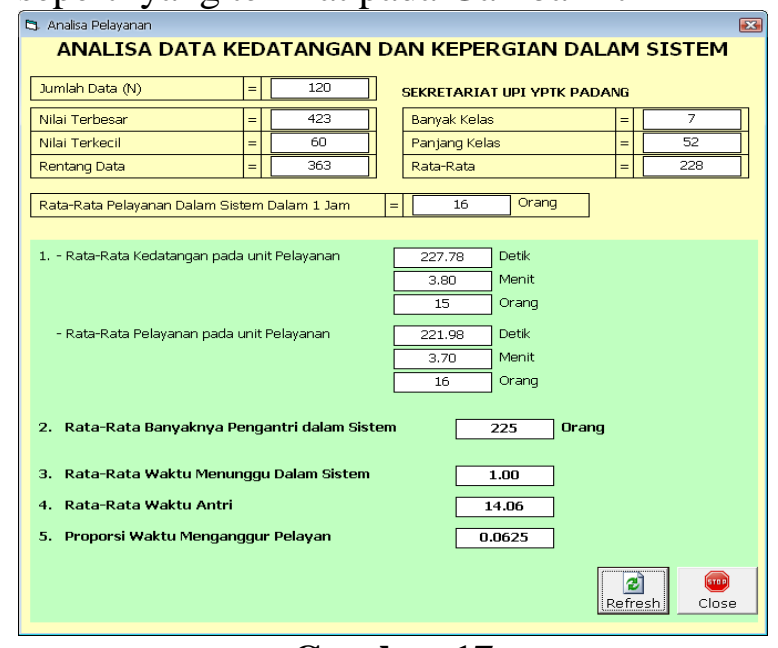

\section{Gambar 17}

Dari hasil pengujian didapat rata-rata Waktu Antar Kedatangan Mahasiswa pada Unit Pelayanan adalah 227.78 detik atau 3.80 menit atau dalam satu jam ada 15 Orang dan Rata-rata tingkat Pelayanan 221.98 adalah 16 Orang dalam satu jam. 
Rata-rata banyaknya pengantri dalam sistem adalah 225 Orang, Rata-rata Waktu Menunggu Dalam Sistem adalah 1 Jam, Rata-rata waktu Antri adalah 14.06 Menit, Proporsi Waktu berhenti melayani adalah 0.0625 menit.

\section{Simulasi Antrian Pada Unit Pelayanan Mahasiswa}

Dalam Simulasi antrian pada unit pelayanan, untuk Waktu Antar Kedatangan dan Waktu Pelayanan Mahasiswa, terlebih dahulu dilakukan perhitungan waktu yang sesuai dengan data sample tiap-tiap kedatangan mahasiswa memasuki unit pelayanan, dilayani oleh unit pelayanan, selesai, dan meninggalkan antrian. Kemudian dibuat frame waktu untuk masing- masing kedatangan dan pelayanan mahasiswa. Simulasi antrian kedatangan mahasiswa pertama memasuki unit pelayanan dapat dilihat pada Gambar 18

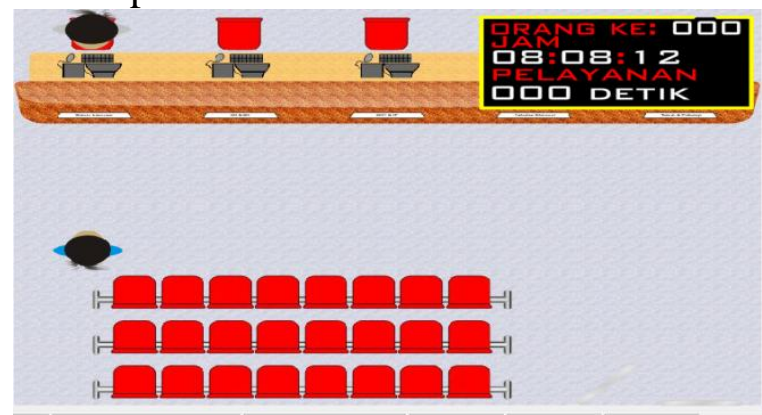

\section{Gambar 18}

pada gambar diatas terlihat kedatangan mahasiswa pertama memasuki unit pelayanan dalam waktu 08.00.12 detik, kemudian meninggalkan unit pelayanan seperti yang terlihat pada Gambar 19

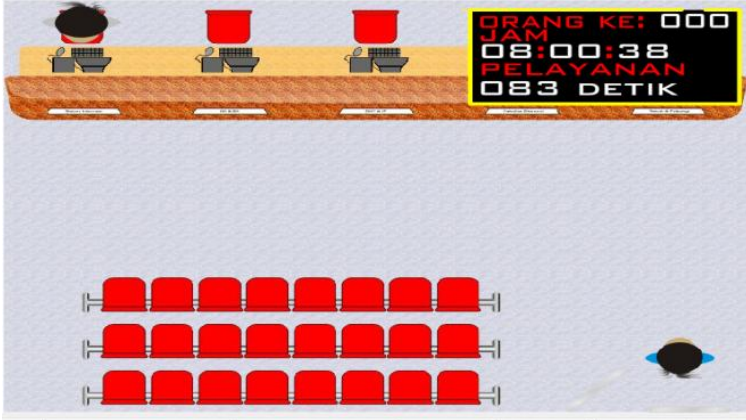

Gambar 19

Pada gambar diatas terlihat mahasiswa pertama meninggalkan unit pelayanan pada waktu 08.00.38 detik, dari hasil simulasi dapat dilakukan perhitungan mahasiswa pertama selesai dilayani dalam waktu 83 detik.Pada pukul 10.04.36 hingga pukul 10.05.22 terlihat jumlah kedatangan mahasiswa pada unit pelayanan meningkat dapat dilihat pada Gambar 20

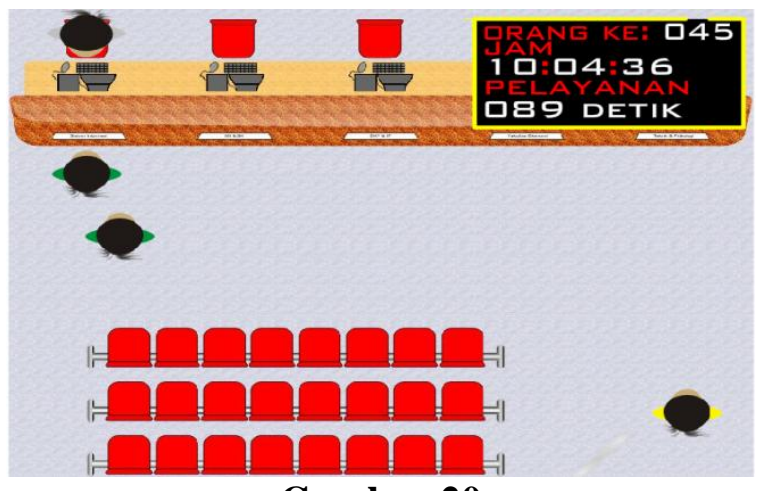

Gambar 20

Pergerakan gambar dapat diatur pergerakannya dengan control play untuk benda bergerak, control pause untuk memberhentikan sementara benda yang bergerak, serta control stop untuk mengulangi pergerakan benda dari posisi awal.dan control Exit seperti yang terlihat pada Gambar 21 


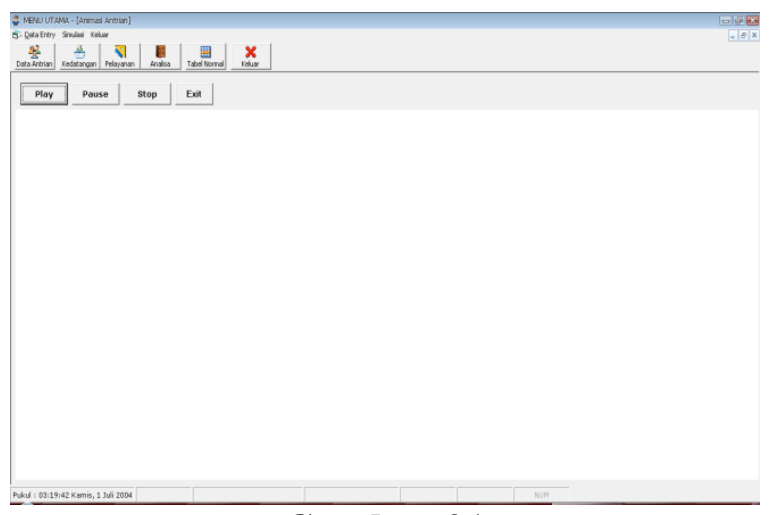

Gambar 21

\section{KESIMPULAN DAN SARAN}

\section{Kesimpulan}

Setelah dilakukan penelitian dan pembahasan tentang masalah simulasi pada antrian yang dilakukan sebelumnya, maka dapat diambil kesimpulan dari masalah antrian tersebut antara lain sebagai berikut :

1. Untuk mengetahui distribusi data dari hasil pengamatan sesuai dengan kajian teoritis dapat dilakukan dengan uji normalitas kolmogorovsmirnovnormal.

2. Distribusi data waktu antar kedatangan dan waktu pelayanan mahasiswa, adalah berdistribusi normal.

3. Rata-rata waktu Antar Kedatangan pada unit pelayanan adalah 227.78 detik atau 3.80 menit atau dalam satu jam ada 15 Orang datang dan rata-rata tingkat Pelayanan adalah 221.98 detik atau 3.70 menit atau dalam satu jam jumlah yang dapat dilayani adalah 16 Orang.

4. Dari hasil Simulasi terlihat bahwa sistem antrian yang ada dalam keadaan seimbang atau steady state Hal ini kemungkinan data diambil pada kondisi perkuliahan normal.
Namun lonjakan akan terjadi bila suatu kalender akademik memungkinkan mahasiswa semakin banyak yang datang untuk mendapatkan pelayanan dibagian pelayanan.

\section{Saran-saran}

1. Unit Pelayanan "UPI-YPTK" Padang untuk menggunakan disiplin antrian FIFO (First InFirst Out) untuk melayani mahasiswa yang datang.

2. Dari hasil simulasi menggambarkan jumlah mahasiswa yang masuk antrian tidak terlalu banyak, sehingga jumlah pelayanan jurusan Sistem Informasi tidak perlu ditambah, namun dari pengamatan langsung pada waktu tertentu memang terdapat lonjakan mahasiswa yang ingin mendapatkan pelayanan, hal ini dikarenakan permintaan layanan bersifat musiman, untuk itu penambahan jumlah yang melayani disesuaikan dengan kebutuhan.

3. Penelitian ini hanya merancang pembuatan model visualisasi animasi antrian maka diharapkan adanya kelanjutan penelitian untuk kesempurnaan dengan aplikasinya.

\section{DAFTAR PUSTAKA}

Andi Supangat, Statistika dalam Kajian Deskriptif Inferensi dan Nonparametik, Kencana Prenada Media Group, Cirebon, 2007

Erma Suryani, Permodelan Simulasi, Graha Ilmu, Yogyakarta, 2006

Thomas J.Kakiay, Dasar Teori Antrian Untuk Kehidupan Nyata, Andi, Yogyakarta, 2004 
Subagyo, Pangestu, dkk. Dasar-dasar Operation Research, BPFE, Yogyakarta.

Bonett Satya Lelono Djati, Simulasi Teori dan Aplikasinya,Andi, Yogyakarat,2007

Simulasi, (Online), (http: //www.mmtits.ac.id/ library/wpcontent/ upload/2008/07/02/prosidingbonettsatya-1-ok.pdf

Tracy Bradley Maples, Discrete Event System Modelling and Simulation, CECS340,2003 